\title{
2 Herder vs. Goethe in Egypt: East and West German Language Courses in Cairo and the Evolution of "German as a Foreign Language" (DaF)
}

\section{Introduction}

On February 27, 1965, Egyptian Deputy Prime Minister Nureddin Tarraf along with Lotte Ulbricht, the wife of East German head of state Walter Ulbricht, ${ }^{1}$ opened the East German Cultural Institute (Kultur- und Informationszentrum, KIZ) in Cairo. ${ }^{2}$ It was situated near Cairo University in a spacious villa with a lush garden. This garden villa at the Western bank of the Nile competed directly with the West German Goethe Institute, which had been established just a few meters from the Tahir Square seven years earlier. In the memories of Egyptians, the East German cultural institute is still called the Herder Institute, although it never officially bore this name. However, it was closely related to the Herder Institute at Leipzig's Karl Marx University which offered language training to international students and other groups of foreigners arriving in the German Democratic Republic (GDR). ${ }^{3}$ The opening of the East German cultural institute KIZ

1 Walter Ulbricht was Chairman of the State Council of the German Democratic Republic.

2 The cultural center has been given various names. It was initially known as the Haus der Deutsch-Arabischen Gesellschaft. Later, “Cultural Center of the GDR” was added. In East German sources, it is mostly called KIZ (Kultur- und Informationszentrum). We also use this name here. 3 The beginnings of the Herder Institute in Leipzig date back to 1951, when a department for foreign students was founded for thirteen Nigerian students at the Workers' and Farmers' Faculty in Leipzig. In 1956, the department was transformed into the Institute for Foreign Students following a decision by the Council of Ministers. The institute was named after Johann Gottfried Herder in 1961 to distinguish it from the Goethe Institute. The name was based on Herder's humanistic ideas and his theories on language. The full official name was Herder-Institut - Vorstudienanstalt für ausländische Studierende in der DDR und Stätte zur Förderung deutscher Sprachkenntnisse im Ausland (Pre-Study Institute for Foreign Students in the GDR and Institution for the Promotion of German Language Skills Abroad). For an overview of the origins of the Herder Institute see Claus Altmayer, “50 Jahre Herder-Institut, 50 Jahre Deutsch als Fremdsprache. Traditionen und Grenzüberschreitungen,” Deutsch als Fremdsprache 44 (2007), 67-74. 
was part of Ulbricht's semi-official state visit to Egypt. ${ }^{4}$ This visit was a significant political success for East Germany in its efforts to gain international diplomatic recognition and therefore provoked outrage in West Germany. Because of this violation of the conditions of the Hallstein Doctrine, which saw the establishment of diplomatic relations with East Germany as an "unfriendly act", West German politicians had threatened to cut economic aid for Egypt or even to break off diplomatic relations to prevent the visit. But Egyptian politicians, in particular president Gamal Abdel Nasser, were unimpressed by the threats and in February 1965 Ulbricht and his wife traveled at the invitation of Nasser from Dubrovnik to Alexandria on the ship Völkerfreundschaft (Peoples' Friendship). ${ }^{5}$

In this chapter we examine the East German cultural institute KIZ in Cairo as a space for encounters and entanglements between Egyptian and German protagonists and as an experimental field for East German cultural diplomacy in the 1960s. A central part of this cultural diplomacy in the 1960s was language teaching. In the 1950s and 1960s, the teaching of German in Egypt gained importance as hundreds of young Egyptians underwent engineering education and technical training at West German universities and colleges. From 1956 onwards, young Egyptians studied in East Germany as well. It was against this background that the Goethe Institute opened a branch in Cairo in 1959. At the time, it was the largest branch of the Goethe Institute in the world and, alongside London, Paris, and New Delhi, one of the most important foreign branches. ${ }^{6}$ When East Germany opened its cultural institute in Cairo and offered German language lessons, the KIZ entered into direct competition with the West German Goethe Institute. We argue that the German-German competition in Egypt, and Egyptian actors pursuing their interests while navigating this conflict, not only influenced and

\footnotetext{
4 Egypt formed a political union with Syria from 1958 to 1961. This "United Arabic Republic" (UAR) was also loosely joined by North Yemen at the end of 1958. This entity of states was meant to form the origin of a pan-Arab confederation. The UAR existed only until 1961, when Syria declared its retreat from the Union. Egypt formally called itself UAR until 1971. In this chapter we use the term Egypt, unless UAR is mentioned in (East German) sources.

5 Behind the scenes, however, the West German side struggled hard to deal with the situation. See William G. Gray, Germany's Cold War: The Global Campaign to Isolate East Germany, $1945-$ 1969 (Chapel Hill, London: The University of North Carolina Press, 2003), 174-182; Young-Sun Hong, Cold War Germany, the Third World, and the Global Humanitarian Regime (New York: Cambridge University Press, 2015), 187-89; Werner Kilian, Die Hallstein-Doktrin. Der diplomatische Krieg zwischen der BRD und der DDR 1955-1973: Aus den Akten der beiden deutschen Außenministerien (Berlin: Duncker \& Humblot, 2001), 123-148.

6 Thomas Kramer, Deutsch-ägyptische Beziehungen in Vergangenheit und Gegenwart (Tübingen: Erdmann, 1974), 229.
} 
shaped the teaching of German in Cairo. It also played an important role in the institutionalization and scientification of German as a foreign language (Deutsch als Fremdsprache DaF), a field that exists until today, but has its roots, partially, in Cold War competition over influence in wooing the postcolonial world.

Larger and inter-German Cold War rivalries and the West German Hallstein Doctrine are considered here as the decisive background of the events. However, we will show that developments surrounding the East German KIZ cannot be evaluated against this background alone. From an Egyptian point of view the German-German competition and the question of whether or not to fully recognize the GDR were less important. The issue was rather a tactical question for the Egyptian side. ${ }^{7}$ Nasserism as a socialist Arab political ideology did not automatically mean that Egypt preferred socialist East Germany to West Germany. Rather, developments in the Middle East conflict played a decisive role in the GDR's relatively successful cultural and language policy in Egypt. Egyptian politicians, notably Gamal Abdel Nasser, demonstrated anti-imperialist sovereignty that did not rely exclusively on socialist countries, but included them as important partners. ${ }^{8}$

Drawing primarily on German archival sources, ${ }^{9}$ we show how Egyptian agency influenced the teaching practice in the East German cultural center and back home in the GDR. The actions of Egyptians can be seen in reports from protagonists from both German states only in double refraction because East German and West German reports followed their respective ideological guidelines. Since the special constellation of German-German competition in Egypt brought about a "triangular relationship", West German agency has to be taken into account as well. In the end, however, Egyptian interests determined the scope that the two German states had for their competing cultural diplomacy in North Africa.

In the first part, we will outline the international political background as well as regional and national constellations and motives that were relevant for decisions on cooperation on the Egyptian side and in both German states. We then return, secondly, to Cairo and zoom into the practice of German-German

7 Hermann Wentker, Außenpolitik in engen Grenzen. Die DDR im internationalen System 19491989 (München: Oldenbourg, 2007), 172-173.

8 The way in which the German-German sensitivities in relations with Egypt were dealt with fits into this model. The construction of the Aswan Dam with Soviet help is certainly the more prominent example.

9 This chapter is based on archival sources from the German Federal Archives (BArch), the Archive of the Parties and Mass Organizations of the GDR (SAPMO-BArch), and the Leipzig University Archive (UAL). 
language teaching after Ulbricht's state visit in 1965. Here we trace the effects of political turmoil, such as the diplomatic crisis between West Germany and the Arab states in 1965, the Six-Day War in 1967, and finally the recognition of the GDR by Egypt in 1969 on the practice of language teaching. Thirdly, we will outline how these early experiences with language teaching in Egypt influenced the institutionalization and conception of language teaching in East Germany. Our research shows that the turning of language teaching into an academic subject, and thus the invention of the subject German as a foreign language (DaF), was spearheaded by East Germany-rather than West Germany-in a process of interactions with non-native speakers. Language teaching in Egypt was an important experience in this respect and serves as an example for the impacts of relations between Africa and the GDR despite the KIZ's relatively short “mooring” in Cairo.

\section{Goethe and Herder Go South}

At this point the question arises of what interest Egyptian politicians had in the two German states and what the Germans from East and West wanted in Egypt. The long-standing German-Egyptian relations had been broken off by Egypt in 1939. Shortly after the Second World War, Egypt resumed trade relations with Germany (western occupation zones). ${ }^{10}$ Following the 1952 revolution, Egypt reoriented its domestic and foreign policy. A decidedly socialist outlook replaced the rather liberal capitalist political orientation of the 1920s to 1940s, when British interests had shaped Egyptian policies. ${ }^{11}$ Egypt had already turned to the Soviet Union and the socialist camp when it concluded an agreement on arms supplies with Czechoslovakia in September $1955^{12}$ and further during the Suez Crisis and the financing and construction of the Aswan Dam from 1956 onwards. ${ }^{13}$ Nasser admired the Soviet economic system, ${ }^{14}$ and, although communists in

10 Wolfgang G. Schwanitz, “Ägypten: Zweierlei Deutsche im Kalten Krieg,” Comparativ 16 (2006): 11-12.

11 Tarek M. Osman, Egypt on the Brink: From the Rise of Nasser to the Fall of Mubarak (New Haven: Yale University Press, 2011), 53-54.

12 For the arms deal see Philipp Muehlenbeck, Czechoslovakia in Africa 1945-1968 (Basingstoke: Palgrave Macmillan, 2016), 91-93. Muehlenbeck emphasizes that connections had already been established between Prague and Cairo before 1955. Czech arms deliveries to Egypt had started in 1946.

13 For Aswan as a paradigmatic case for development projects between the frontlines of the Cold War see Dirk van Laak, Weiße Elefanten. Anspruch und Scheitern technischer Großprojekte im 20. Jahrhundert (Stuttgart: Deutsche Verlagsanstalt, 1999), 107-108.

14 Odd Arne Westad, The Cold War. A World History (New York: Basic Books, 2017), 453. 
Egypt were in a difficult position because Nasser feared their political influence at that time, Nasser emphasized that he was not an anti-communist and that he wanted to further develop relations with the socialist states. ${ }^{15}$ So while Egypt did not pursue a declared socialist policy, it was one of the countries that took up socialist ideas and was interested in closer relations with the socialist states of Eastern Europe.

However, the most important orientation that Egypt shared with the GDR was not so much a declared socialism, but rather a strong anti-imperialism. This anti-imperialism shaped Egyptian international policy. Egypt was an important player in Third World movements of the 1950s and 1960s. In the 1960s, it was one of the leading powers in the Non-Aligned Movement (NAM) and at the same time a hub of Pan-Arabism, a "sanctuary of 'revolutionists' from all over the Arab world," ${ }^{16}$ as well as a supporting power of political Pan-Africanism. ${ }^{17}$ At the same time, Nasser initiated an ambitious domestic development program. Therefore, Egypt had a strong economic interest in entertaining good relations with both German states, hoping for expertise and technology as well as foreign exchange and loans.

Since Egypt was a center of political pan-Arabism and at the same time a center of the political decolonization movement in Asia and Africa, relations with Egypt were important for both German states as well. East German officials saw Egypt as an important diplomatic gateway to Africa and the Arab world ${ }^{18}$ but were also interested in economic relations, particularly the import of cotton for its textile industry. Despite the Hallstein Doctrine, East Germany succeeded in establishing economic relations with Egypt, which laid the foundation for further

15 Kilian, Hallstein-Doktrin, 114.

16 Osman, Egypt on the Brink, 65-66.

17 For Egypt as a hub of decolonization and a center of the Afro-Asian movement see Eric Burton, "Hubs of Decolonization. African Liberation Movements and Eastern Connections in Cairo, Accra and Dar es Salaam”, in Southern African Liberation Movements and the Global Cold War "East”: Transnational Activism 1960-1990, ed. Lena Dallywater, Helder A. Fonseca, and Chris Saunders (Berlin: De Gruyter, 2019); Reem Abou-El-Fadl, "Building Egypt’s Afro-Asian Hub: Infrastructures of Solidarity and the 1957 Cairo Conference,” Journal of World History 30 (2019). For an overview over the Non-Aligned Movement (NAM) see Jürgen Dinkel, The Non-Aligned Movement: Genesis, Organization and Politics, 1927-1992 (Leiden, Boston: Brill, 2018). For Egypt in the NAM see Lorenz Lüthi, “The Non-Aligned Movement and the Cold War, 1961-1973,” Journal of Cold War Studies 18 (2016).

18 In East Germany, however, Egypt, like the entire Maghreb, was mainly categorized as belonging to the Arab world, although it is located on the African continent and had close ties to African states, especially in the 1960s. See Martin Praxenthaler, Die Sprachverbreitungspolitik der DDR. Die deutsche Sprache als Mittel sozialistischer auswärtiger Kulturpolitik (Frankfurt, Berlin: Peter Lang, 2002), 50-51. 
cultural and later diplomatic relations. The initiative for trade relations initially came from Egypt. An Egyptian delegation visited East Berlin in July 1950 in search of new markets for cotton. The first trade agreement between the GDR and a non-aligned country was signed with Egypt in 1953 and a GDR trade agency subsequently opened in Cairo in $1954 .{ }^{19}$ In October 1958 the German-Arabic Society (DAG) was founded in East Berlin. ${ }^{20}$ The foundation of the society was a first step to institutionalize the cultural cooperation of the GDR with the Arab countries. The aim was to support the "Arab peoples' struggle against imperialism". ${ }^{21}$

West Germany wanted to maintain its economic relations with Egypt and at the same time prevent diplomatic success of East Germany by all means, fearing that a break with Egypt over the Hallstein Doctrine would compel other Arab governments to follow the Egyptian example. A crucial issue in Egypt's relations with Bonn was the question of the diplomatic recognition of Israel. ${ }^{22}$ The relations of both German states with Egypt remained relatively stable until 1965, when the West German and British press published articles on arms deliveries from West Germany to Israel. The reports triggered a series of events that became known as the "Middle East crisis"23 of West German foreign policy. It led to the invalidation of the Hallstein Doctrine, and eventually to diplomatic recognition of East Germany by several Arab states. After the West German-Israeli treaties had become known President Nasser saw Egypt's security interests threatened. ${ }^{24}$ The Egyptian government now decided to restrict relations with West Germany and to develop a closer cultural and economic relationship with East Germany instead. Egypt suffered from a lack of foreign exchange during this period,

19 Kilian, Hallstein-Doktrin, 104-108.

20 SAPMO-BArch, DY 13/3340, Statut der Deutsch-Arabischen Gesellschaft in der Deutschen Demokratischen Republik, no date.

21 Liga-Akte 209: Gründungsunterlagen der Deutsch-Arabischen Gesellschaft (DAG), cited in Wolfgang Schwanitz, "Streng vertraulich? Aus den Akten der Deutsch-Arabischen Gesellschaft 1958-1969,” in Berlin-Kairo: Damals und heute. Zur Geschichte deutsch-ägyptischer Beziehungen, ed. Wolfgang Schwanitz (Berlin: DÄG, 1991), 91.

22 For Cold War polarization in the Middle East and the conflict over Israel see Salim Yaqub. "The Cold War and the Middle East", in The Cold War in the Third World, ed. Robert McMahon (Oxford: Oxford University Press, 2003).

23 Nahostkrise (Middle East crisis) was a common term in the West German press to describe the events surrounding the recognition of Israel and the breaking off of diplomatic relations by the Arab states, e.g. "Nahostkrise: Tränen im Waldorf Astoria." Der Spiegel 9, February 24, 1965, 25-33.

24 “Drahtbericht Federer vom 25.01.1965”, in Akten zur auswärtigen Politik der Bundesrepublik Deutschland, ed. Mechthild Lindemann and Rainer A. Blasius (München: Oldenbourg, 1999), 192. 
and East Germany offered government loans, commercial credits, and experts. ${ }^{25}$ Walter Ulbricht was invited to Cairo. In an interview with the West German news magazine Spiegel, Nasser replied to the question of why he had invited Ulbricht to Cairo after letting him wait for almost two years: "We felt betrayed by West Germany."26

West German politicians were unsure how to react to Ulbricht's Cairo visit, discussing options of ignoring and punishing throughout February. "Stalingrad at the Nile", as a West German magazine called the disaster in a rather shrill headline, caused some turbulence. ${ }^{27}$ It was feared that Egypt would ultimately recognize East Germany if West Germany exerted too much pressure. Eventually, this diplomatic confusion was the beginning of the end of the Hallstein Doctrine as West Germany could neither afford to break off relations nor act according to the doctrine. ${ }^{28}$

25 Gray, Germany's Cold War, 172. The credits were granted in the East German convertible currency Valuta Mark (VM) and included VM 200 million (approximately US\$50 million) in government credits and VM 130 million in commercial credits. Some of the credit commitments contained old credits from a 1958 agreement that had not been exhausted (VM 40 million). Among other things, these loans had been used to buy GDR machines for cotton processing and to set up a textile combine in Shibin el-Kom.

26 Interview by Dieter Schröder and Conrad Ahlers with Gamal Abdel Nasser, "Sie können sich doch nicht ewig erpressen lassen!” in Der Spiegel 9, February 25, 1965, 34. In this interview, Nasser also made it clear that Egypt would probably recognize the GDR if West Germany was to cease its economic aid because of the visit of Ulbricht to Egypt. He also stressed that Egypt would generally not react to Western threats.

27 Christ und Welt, February 5, 1965, quoted in Amid Das Gupta, "Ulbricht am Nil: Die deutschdeutsche Rivalität in der Dritten Welt,” in Das doppelte Deutschland: 40 Jahre Systemkonkurrenz, ed. Udo Wengst and Hermann Wentker (Berlin: Ch. Links, 2008).

28 Gray, Germany's Cold War, 173-176; Kilian, Hallstein-Doktrin, 153. For an analysis of the West German discussions around the Ulbricht visit and its impact on the implementation of the Hallstein Doctrine see also Hong, Cold War Germany, 245-249. 


\section{German-German Kulturkampf ${ }^{29}$ in Cairo}

\section{5-1967: "Sprechen Sie Deutsch?” The First Years of Direct Competition}

Competition between the two German states in Egypt was carried out through means of cultural diplomacy. Between 1957 and 1960, the Politburo of the East German ruling party, the Socialist Unity Party (SED), had passed several resolutions stipulating that cultural centers focusing on language instruction should be opened in non-socialist countries. ${ }^{30}$ From 1965 on, language teaching became an important part of on-site cultural diplomacy in Cairo. ${ }^{31}$ Set up in a villa near Cairo University, the newly established East German cultural institute KIZ had five large classrooms, several offices, and a library. A concert grand piano was handed over to the staff at the ceremonial opening. The grand piano later stood in the event hall, which was solemnly called the "grand hall." 32 The first director of the KIZ was the orientalist Klaus Timm, while the first chief instructor was the linguist Gerhard Helbig from Leipzig's Karl Marx University.

When Gerhard Helbig arrived in Cairo together with his wife Agnes Helbig at the end of December 1964-two months before Ulbricht's state visit to Egypt-he encountered a "completely empty, poorly maintained house." He spent the first few months supervising the preparation of classrooms and providing the complete equipment so that German lessons could take place there. At the beginning of February 1965, advertisements for a German course were placed in several Egyptian newspapers. More than 110 Egyptians personally registered with Agnes Helbig in a provisionally furnished office at the center. ${ }^{33}$

Paradoxically, the high number of registrations was a reason for concern rather than joy. The head of the KIZ, Klaus Timm, was originally opposed to admitting so many Egyptians to German lessons in the new institute. Due to a shortage of personnel, he only wanted to approve small courses with a maximum of six to ten participants. Gerhard Helbig, who was the only German in-

29 Originally the German term Kulturkampf (cultural struggle or culture war) refers to Chancellor Otto von Bismarck's sanctions against (political) Catholicism in 1870s Germany, but it is used for cultural conflicts in other times and places as well.

30 The first of these centers was opened in Helsinki in 1960.

31 Praxenthaler, Sprachverbreitungspolitik, 233-234, 260-262.

32 BArch, B 307/96, Letter Dr. Klopfer to Dr. Hutter, Goethe-Institut Zentralverwaltung Abt. I, October 21, 1965.

33 SAPMO-BArch, DR3/II/B839, Dr. Gerhard Helbig, Bericht über die Arbeit des Deutsch-Lektorats Kairo im Frühjahrssemester 1965, July 10, 1965. 
structor at the KIZ during the first few months, however, managed to keep the German courses open for a larger number of interested people by referring to the competition with West German cultural diplomacy in Cairo. "For the displacement of the Goethe Institute, the effectiveness of the language institute is very important. So far, the Goethe Institute has held all these positions in its hands," Helbig explained his commitment to the East German Foreign Office (MfAA) and the Herder Institute. German lessons should be offered at more favorable conditions than at the Goethe Institute but not free of charge, as otherwise, Helbig assumed, "the value of teaching would be reduced in Arab eyes."34

The classes started in March 1965. Apart from regular German classes, the KIZ also offered individual lessons for Egyptian personalities considered as especially important, including not only prospective engineers or other specialists who were to study in the GDR but also members of the Egyptian elite who were interested in (East) German lessons. ${ }^{35}$ Two state secretaries of the Egyptian Ministry of Education attended private lessons. Another visitor was Mahmoud ElHefny, the brother-in-law of Deputy Prime Minister Nureddin Tarraf. El-Hefny was one of Egypt's most respected musicologists and chaired a club for Egyptians that had graduated in Germany (Klub der in Deutschland graduierten Ägypter) from 1963 to 1973. In the 1920s, El-Hefny had studied medicine and musicology in Rostock and Berlin. He had received his doctorate in musicology from the Friedrich Wilhelm University ${ }^{36}$ of Berlin in 1931. Obviously, El-Hefny already spoke German and wanted to refresh or deepen his knowledge and invested in the maintenance of a social network. ${ }^{37}$

The German courses were an essential part of the KIZ, and they shaped the image of the institute to the outside world. The courses were technically good, which the West German competitors readily acknowledged. Additionally, like the Goethe Institute, the KIZ offered its visitors exhibitions and concerts, and subtitled East German films as well as scientific and political lectures and discussion evenings.

After some hesitations following Ulbricht's visit to Cairo, the West German government finally decided to impose sanctions against Egypt. West Germany announced that it would cease providing economic aid to Egypt. When Chancel-

34 SAPMO-BArch, DR3/II/B839, Dr. Gerhard Helbig, Bericht über die Arbeit des Deutsch-Lektorats Cairo im Frühjahrssemester 1965, July 10, 1965.

35 Ibid.

36 Now Humboldt University.

37 For biographical information about Mahmoud El-Hefny see Gerhard Höpp, Texte aus der Fremde. Arabische politische Publizistik in Deutschland, 1896-1945. Eine Bibliographie (Berlin: Das Arabische Buch 2000), 51-52. 
lor Ludwig Erhard on March 7, 1965 announced that West Germany was willing to fully recognize Israel, Egypt and nine other Arab states broke off their relations with the Federal Republic of Germany (FRG). As a result, West Germany was forced to close its embassy in Cairo and recall the ambassador. "Nowhere in the world have I seen such an impudent people as the West Germans", Nasser declared in a speech one day after Erhard's announcement to recognize Israel. ${ }^{39}$

Despite the breakdown of relations, the staff of the embassy's cultural department remained in Cairo. ${ }^{40}$ The Goethe Institute and the (West) German Academic Exchange Agency DAAD (Deutscher Akademischer Austauschdienst) were able to continue their work for the time being. The (West German) Federal Foreign Office hoped that the Goethe Institute would be able to take on some of the diplomatic tasks of the embassy that no longer existed. ${ }^{41}$ Although West Germany had lost its embassy in Cairo, East Germany was unable to open its own. For Nasser, political pan-Arabism was central and he refused full diplomatic recognition of East Germany not because of West German sensitivities, but to avoid conflict between the Arab states which were divided over this issue. ${ }^{42}$

Thus, the cultural diplomats of both German competitors were finally at eye level. Without diplomatic representation for both German states, cultural diplomacy became more central. This constellation with a "downgraded" West Germany at diplomatic eye level with East Germany is historically unique. It shows that southern agency, in this case Egyptian diplomacy, could influence and limit the scope of action of the northern partners considerably.

Although there were signals from the Egyptian side not to obstruct the work of the Goethe Institute and the DAAD, the political situation nevertheless led to restrictions. The Egyptian government banned Egyptian civil servants from visiting the Goethe Institute without ministerial permission. Appointments that the Goethe Institute had already made with ministry civil servants were cancelled at short notice, Egyptian officials rejected invitations, and the "previously approved use of venues was prohibited." ${ }^{43}$ In the months following the diplomatic

38 See Kilian, Hallstein-Doktrin, 132, 141-148.

39 Nasser, cited in Kilian, Hallstein-Doktrin, 142.

40 For a detailed description of the break-off of diplomatic relations see Dalia Abu Samra, "Deutschlands Außenpolitik gegenüber Ägypten: Abbruch und Wiederaufnahme der diplomatischen Beziehungen 1965-1972” (PhD diss., Freie Universität Berlin, 2002), 86-87.

41 DAAD, Jahresbericht 1965, 158.

42 Schwanitz, "Zweierlei Deutsche," 19-20.

43 BArch, B 307/31, Bericht Dienstreise Direktor Werner Ross in den Nahen Osten, April 26, 1965. 
withdrawal, it became increasingly difficult for the staff of the Goethe Institute and the DAAD to obtain visas and work permits for their stay in Egypt. ${ }^{44}$

Intra-German competition in language policy created a situation that various actors on the Egyptian side could use to their advantage. They sometimes played both German sides off against each other in order to get free German lessons or instructor positions for Egyptian universities or colleges. ${ }^{45}$ Some examples might illustrate how the competition could be exploited for personal ends. In order to keep the Egyptians close to the West German side, the Goethe Institute decided to soften the positions of some state secretaries with small favors. Among others, State Secretary Mustafa Hassan was invited to a longer trip to Germany at the expense of the Goethe Institute, and a two-year scholarship was procured for the son of State Secretary Sayed Mohamed Roha. In addition, they promised a free additional holiday course for Egyptian German teachers in Munich. In another case the Goethe Institute responded to the GDR's offer to the Egyptian Ministry of Education for 12 teachers of German at secondary and high schools in Egypt and 20 training scholarships for German teachers in Leipzig by offering the Egyptian Ministry of Education a two-year training course for four German teachers in Munich and additional further training measures for all Egyptian German teachers with the possibility of taking part in a summer language course in West Germany. ${ }^{46}$

In the summer of 1965, the dean of the German department of the language school in Zeitoun, Antoum Chalaby Maher, approached the Goethe Institute and demanded two additional teachers for his institute. Otherwise he would fall back on the offer of East Germany, which had already, he claimed, promised him two teachers. The Goethe Institute responded favorably to the demand. ${ }^{47}$ The fear of an East German breakthrough was deep-seated. The executive board of the

44 Several lecturers reported that the granting of visas was subject to harassing conditions. Large quantities of bribe (baksheesh) had to be paid and many forms signed by different authorities had to be submitted. The waiting time, begging, and errands now took several weeks of working time. BArch, B 307/31, Bericht Dienstreise Direktor Werner Ross in den Nahen Osten, April 26, 1965.

45 BArch, B 307/96, Vermerk Klopfer, Aktivitäten SBZ-Institut, April 20, 1966; BArch, B307/96, Betr.: Situation des Goethe-Institut[s] in Cairo, no date; BArch, B 307/96, Italienische Botschaft an das Auswärtige Amt, SBZ-Aktivität in Zusammenhang Deutschunterricht VAR, Lahn, June 16, 1966; SAPMO-BArch, DR3/II/B509, HA Internationale Beziehungen, Brief an Geerhardt, MfAA, October 31, 1967.

46 BArch, B 307/96, Aktennotiz Dr. Klopfer, Betr. Besuch von Dombois im Ministerium für Erziehung und Universität Cairo, February 9, 1966; BArch, B 307/96, Klopfer an Zentralverwaltung, Betr. Versuch SBZ in Deutschunterricht in Oberschulen einzudringen, March 23, 1966. 47 BArch, B 307/96, Betr.: Zur Situation des Goethe-Institut in Kairo, August 10, 1965. 
Goethe Institute agreed to do everything in its power to fend off the East German advances: "If the SBZ [Soviet Occupation Zone] ${ }^{48}$ had succeeded in making a major slump in this direction, the consequences would not be foreseeable. That's why every effort must be made to send as many good people as possible in sufficient numbers." ${ }^{49}$

When a position as a language inspector for German lessons at the Egyptian Ministry of Education became vacant, East Germany proposed to fill it. Until then, three inspectors of the Goethe Institute had been closely involved in the professional supervision of the Egyptian German instructors. Since the Egyptian Ministry of Education postponed the decision for some time, two KIZ employees offered Egyptian German instructors jobs at the KIZ in Cairo and distributed symbolic awards such as "knowledge medals" to the course participants. ${ }^{50}$ When the Goethe Institute protested that the previous supervision of German lessons at Egyptian schools was no longer guaranteed and that on the other hand the awarding of "FDJ [Free German Youth] ${ }^{51}$ medals" by non-authorized East German citizens at Egyptian schools was equivalent to the GDR's recognition under international law, Egyptian state secretaries replied that the West German arms deliveries to Israel had not been forgotten. ${ }^{52}$ Here again the Egyptians dealt with the case without showing much interest in the complicated details of German-German competition and rather bluntly asserted their focus on the Israeli case.

The existence of two German language institutes in Egypt and the ideologically charged competition led to the close observation of each other's work. In their Kulturkampf, Germans occasionally tried to instrumentalize Egyptians as informers and cultural saboteurs. The Goethe Institute, on the instructions of the Federal Foreign Office, encouraged its Egyptian staff to attend KIZ events in order to report on them and carry out "possible countermeasures." 53 On the

48 Sowjetische Besatzungszone (SBZ) was the term used for the sector of Germany which was occupied by the Soviet Union since 1945. Even after the founding of the GDR in 1949, the term was often used in West Germany instead of the abbreviation GDR, since the GDR was not recognized as a sovereign state.

49 BArch, B 307/32, Vorstandsprotokoll Goethe-Institut, March 4, 1966.

50 BArch, B 307/96, Vermerk Dvorak, Aktivitäten SBZ-Institut, April 19, 1966.

51 FDJ was the East German youth organization Freie Deutsche Jugend, associated with the ruling party SED.

52 BArch, B 307/96, Vermerk Klopfer, Aktivitäten SBZ-Institut, April 20, 1966. More examples of the various and sometimes absurd West German discussions about whether or not little flags, mentions of the name "GDR" in conference documentations or East German orders meant recognition of the GDR can be found in Kilian, Hallstein Doctrine.

53 BArch, B307/96, Schreiben Auswärtiges Amt an Goethe-Institut, Betr. Kontakte von Mitarbeitern der Kulturinstitute mit Vertretern der sowjetisch besetzten Zone, May 5, 1966. 
other hand, East German language teachers visited Goethe Institute events and wrote detailed reports on them. In May 1966, the Federal Foreign Office completely prohibited the German staff of the Goethe Institute and the DAAD from contacting members of the GDR Cultural Center. Instead, their own Egyptian local staff was chosen to obtain information. They should apparently respond to the East German offer for a further training course for Egyptian German instructors, in order to learn more about the structures and working methods of the East German Institute. ${ }^{54}$ The Egyptian instructors later stated that the East German chief instructor Peter Schumann was approaching them with special offers. He offered them to change to the East German Institute for a better salary and promised the possibility of free further training at the Herder Institute in Leipzig. The Egyptian instructor Samir Boalos, for example, reported that East Germans told him that the KIZ had excellent relations with Egyptian civil servants and secretaries of state, which would certainly benefit the professional career of German instructors. ${ }^{55}$ Whether this East German offer really existed can only be inferred from the reports of the Egyptian instructors, but not from the documents of the GDR. It is also possible that the Egyptian instructors, in playing Germans off against each other, tried to increase their wages at the Goethe Institute and hoped for invitations to language courses in West Germany.

The East German KIZ managed to establish itself in Cairo within a few months. By fall 1966, more than 100 language students had enrolled in the courses. In instructor Gerhard Helbig's view, one reason for this was a modern, fully equipped electronic classroom, with television, film projector, and record player. It was not a widespread practice at the time to include these media in language teaching. According to Helbig, the East German classroom was looked upon with envy by West German competitors. ${ }^{56}$ If that was the case, this might be one of the rare occasions where East German technical equipment in development cooperation was superior to West German one. From March 1967, the West German television course Guten Tag was broadcasted on Egyptian television. ${ }^{57}$ The broadcasting was discontinued in the spring of 1968 and replaced by the

54 BArch, B 307/96, Rundschreiben Auswärtiges Amt an Zentralverwaltung Goethe-Institut, Betr. Kontakte von Mitarbeitern der Kulturinstitute mit Vertretern der sowjetisch besetzten Zone, May 5, 1966.

55 BArch, B 307/96, Aktennotiz Dr. Klopfer, Betr. Besuch unserer Ortskraft Samir Boalos im SBZ, February 7, 1966.

56 SAPMO-BArch, DR3/II/B839, Bericht über die Arbeit des Deutsch-Lektorats Cairo im Frühjahrssemester 1965, Dr. Gerhard Helbig, July 10, 1965.

57 BArch, B 370/41, Aktennotiz, betr. Internationale Erfolge des Fernsehkurses Guten Tag, October 19, 1967. 
East German television course Sprechen Sie Deutsch? The course was meant to be a pilot project for GDR TV courses in the Arab world and other countries and was given as a gift to the Egyptian television. For a period of three years, this East German course ran weekly on the Egyptian State Channel Five. ${ }^{58}$ Accompanying the course, the KIZ offered consultations in its own cultural center as well as in the Egyptian cultural centers in various cities. ${ }^{59}$ The rapid successes encouraged the GDR leadership to strengthen its cultural policy work in Egypt on the basis of a decision from the GDR's Council of Ministers in summer 1966 to expand foreign information activities (Auslandsinformation), as the propaganda work was called, in the Arab countries. The decision provided for the opening of two new cultural centers in Aleppo and Alexandria. ${ }^{60}$ In addition, the training and further education of Egyptian and Syrian German teachers was intensified. ${ }^{61}$

\section{7: Teaching German after the Six-Day War}

The Six-Day War in June $1967^{62}$ was a turning point for the Egyptian-German triangle relationship. Since West Germany supported Israel, the political mood and the opinion of the Egyptian authorities and in institutions quickly changed from suspicious to hostile. Politicians frequently referred to the "anti-Arab Federal Republic" in public. ${ }^{63}$ West German instructors wrote about a "hostile attitude" of the Egyptian population in their reports. The staff of the Goethe Institute even reported that they felt a "climate of fear." 64 Egyptian authorities began to put pressure on the Goethe Institute and the DAAD as residence permits were not extended and work permits could only be obtained with great effort. The Egyptian secret service began to openly monitor employees of the Goethe Institute. ${ }^{65}$ After Egyptian protesters in Alexandria had set the American and British consulates on fire in the name of anti-imperialism and tried to do the same at the Goethe Institute, which was protected by the police, the Goethe Institute decided to

58 Praxenthaler, Sprachverbreitungspolitik, 310-311.

59 SAPMO-BArch, DR3/II/B1022c, Tätigkeitsbericht Lektorat KIZ Kairo 1968/69, February 24, 1969.

60 Ibid.

61 SAPMO-BArch, DY30/JIV2/3/1188, Beschluß zur Verstärkung der auslandsinformatorischen Tätigkeit der DDR in den arabischen Schwerpunktländern, June 10, 1966.

62 For the Six-Day War between Israel on one side and Egypt, Jordan, and Syria on the other, which ended in a complete disaster for the Arab side see Westad, Cold War, 459-461.

63 BArch, B 212/21181, 000219/1 Jahresbericht DAAD Kairo 1969, Eckmann, February 11, 1970.

64 BArch, B 307/222, Tätigkeitsbericht GI Alexandria 01.01.1967-30.06.1967, July 13, 1967.

65 BArch, B 307/233, Ferkinghoff, 1. Halbjahresbericht 1967, Kulturarbeit, no date. 
close the offices in Cairo and Alexandria temporarily. Language courses were discontinued and the upcoming examinations postponed until further notice. The head office in Munich was firmly expecting both branches to be permanently closed by the Egyptian government and was already planning to transfer the staff to other countries. ${ }^{66}$

East Germany's cultural diplomats took advantage of this situation immediately. The KIZ remained open and classes continued during the war. Just one day after the closure of the Goethe Institute, the East German KIZ advertised in Egyptian newspapers that the examinations planned by the Goethe Institute would be held by the "German Cultural Centre of the GDR - Arab-German-Society". ${ }^{67}$ As a result, many of the Goethe Institute's language course participants, especially from the intermediate and advanced levels, moved to the KIZ. ${ }^{68}$

In late 1967, a brochure entitled "In the Name of Goethe - The Goethe Institute, a Weapon of West German Imperialism” appeared in Egypt. The brochure, written entirely in Arabic, was printed in East Berlin by Panorama, a publisher of the GDR's Foreign Press Agency. It was distributed free of charge in large numbers to state authorities, ministries, and the press. Excerpts from the brochure were also published in the Egyptian magazine Al-Magalla. The GDR obviously wanted to use the anti-imperialist, anti-Western mood and hoped to convince the supposedly communist, GDR-friendly or anti-imperialist minds in ministries, authorities, and the press of the danger represented by the Goethe Institute. ${ }^{69}$ The campaign was seemingly successful, but this was probably due to the political circumstances rather than the persuasiveness of the East German propaganda. In a way the disaster of the Six-Day War achieved what the GDR propaganda had not in the previous years: to demonize West Germany as an imperialist power.

Since West Germany did not want to leave the field to the Eastern competitors, the Goethe Institute re-opened its doors just after a few weeks. But Ludwig Erhard's public support for Israel had taken its toll. The number of participants in language courses at the Goethe Institute dropped rapidly after the war. In September 1967, more than 30 students moved from the Goethe Institute to the KIZ. An Egyptian language student wrote to the Goethe Institute explaining his decision: "I refuse to continue taking language lessons with you. It would be embarrassing and painful for me if I continued to study in your institute which belongs

66 BArch, B 307/10, Protokoll Abteilungsleiterkonferenz Goethe-Institut, July 3, 1967.

67 BArch, B 307/223, H.R. Reinstrom, Vermerk, no date.

68 BArch, B 307/233, Halbjahresbericht Goethe-Institut Kairo, 1.07. - 31.12.1967, no date.

69 The brochure can be found in BArch, B 307/273, Korrespondenz Kairo, no date. 
to the West German government, a government that clearly participated in the dirty, armed hostilities against the great Arab homeland."70

Egyptian authorities now stipulated that all West German cultural events required a permit from the Egyptian Ministry of Interior and could not take place outside the premises of the Goethe Institute. ${ }^{71}$ Additionally, West Germany now had to pay social insurance to all local Egyptian DAAD and Goethe Institute employees which resulted in enormous bureaucratic effort and financial costs. The Goethe Institute, the DAAD and the West German Cultural Department suspected that this compulsory insurance had been introduced under pressure from East Germany. ${ }^{72}$ This shows a characteristic pattern that shaped German-German perceptions: in the bipolar logic of system competition, both sides assumed that their (German) rivals orchestrated the restrictions and Egyptians were nothing but puppets. Egyptian initiatives and motives, such as anti-imperialism or anti-Zionism, rarely appear in the reports of both German sides. Once more, the intra-German rivalry provided several advantages for Egyptian course participants. With some skill, it was possible to get free language lessons. The director of the Egyptian Cultural Centre in Zagazig received free German lessons at the East German KIZ by mentioning that the Goethe Institute had offered him free lessons. Other German learners succeeded in enrolling late in courses of the KIZ, arguing that language courses could also be taken at the Goethe Institute. ${ }^{73}$

East Germany attempted to exploit the weak position of West Germany in Egypt as a result of the Six-Day War to gain a foothold in the Egyptian university landscape. In addition to three West German instructors, the Language School at Zeitoun also hired an East German instructor to run its language laboratory in September 1967. This caused problems, because the shift in Egyptian politics in favor of the GDR did not mean that all Egyptians welcomed this change. The Egyptian head of the language school, Antoum Chalaby Maher, did not conceal his sympathy for the Goethe Institute and asked the East German instructor Klaus Neubert to stick to the (West German) curriculum and teaching material. However, since Neubert had been instructed by his superiors not to use West German material for political reasons, he had to produce his own teaching material. ${ }^{74}$

70 BArch, B 307/223, Enclosure in Halbjahresbericht Goethe-Institut Kairo, 1.07-31.12.1967, no date.

71 BArch, B 307/222, Tätigkeitsbericht GI Alexandria 01.01.1968-30.06.1968, no date.

72 BArch, B 307/233, Aktennotiz, May 9, 1967.

73 SAPMO-BArch, DR3/II/B1022b, Bericht des Lektorats am KIZ Kairo WS 1967/68, March 1968. 74 SAPMO-BArch, DR3/II/B1022b, Dietrich Engel, Bericht des Lektorats am KIZ Kairo, March 1968. 


\section{9: Recognition}

Egypt turned closer to the Soviet Union and Eastern European States after the Six-Day War. This promoted the diplomatic aims of the GDR. Cultural relations were already deepened at the end of 1968. To this end, a joint cultural commission was founded and a new joint "Working program for cultural and scientific cooperation" was concluded..$^{75}$ One of the most important goals of the program was the promotion of GDR German teaching in Egypt. The aim was to replace West Germany from its traditional positions in the field. Abdul Wahab El-Borolosy, Egyptian Minister of Research and Higher Education, and representatives of the Egyptian Ministry of Education promised at a meeting with the Cultural Department of the Consulate General and the KIZ to support the ideas of the GDR. ${ }^{76}$

On July 10, 1969, the Egyptian and East German governments announced the establishment of diplomatic relations. The West German Government's reaction did not contain the threat of countermeasures, which was tantamount to a change in the policy of non-recognition towards the GDR. The recognition of the GDR was still described as a hostile act by West German officials, but no retaliatory measures such as the breaking off of trade relations were used. ${ }^{77}$ The breakthrough at the diplomatic level was also the breakthrough in the field of German as a foreign language (Deutsch als Fremdsprache, DaF) for the GDR in Egypt. With the opening of the embassy, the DaF working group was immediately founded, which further determined and coordinated the tasks of the cultural center and the work of East German instructors at Egyptian universities. ${ }^{78}$ Some West German instructors were replaced by East German instructors. As one of the first measures, the East German instructors introduced GDR teaching material. ${ }^{79}$

The change of mood in Egypt also led to a significant increase in the number of applicants for language courses at the KIZ. In the spring of 1970, the enrolment

75 SAPMO-BArch, DR3/II/B837, Information über den Stand der Beziehungen auf dem Gebiet des Hochschulwesens mit der VAR, May 19, 1970.

76 SAPMO-BArch, DR3/II/B1048 Brief von Dr. Konschel an Dr. Merkel (MfAA), February 18, 1969.

77 Rainer Büren, "Die arabischen Staaten in der außenpolitischen Konzeption der Bundesrepublik Deutschland," in Araber und Deutsche. Begegnungen in einem Jahrtausend, ed. Friedrich Kochwasser and Hans Roemer (Tübingen/Basel: Erdmann), 22; see also Kilian, Hallstein-Doktrin, $162-163$.

78 SAPMO-BArch, DR3/II/B1507/1a, Cheflektor Steinecke, Arbeitsplan des Lektorats Kairo für das Studienjahr 1971/72, October 13, 1971.

79 SAPMO-BArch, DR3/II/1507/1b, Erika Endesfelder, Die Einflußnahme auf den Fremdsprachenunterricht Deutsch in der VAR durch die DDR und die BRD-Institutionen, Anfang 1971, no date. 
for the courses had to be stopped after only two days due to the large number of applicants. Since East German officials demanded to enroll preferably those Egyptians who "appear to be important for the foreign information objective," the tuition fees for "students and housewives" were increased by 50 percent because the DaF working group considered these to be of little relevance. ${ }^{80}$ It becomes clear here that the main objective of the language courses was to achieve political goals. Propaganda for the GDR, the above mentioned "foreign information," was a mandatory part of the language courses. ${ }^{81}$ The aim was to convince Egyptian society of the advantages of the socialist GDR over the "imperialist" FRG. In contrast, "housewives" and "students" were obviously not regarded as important multipliers and were therefore excluded as far as possible.

In the 1970s, however, East German propaganda became less important in language teaching and made way for a more pragmatic approach. Already in spring 1970, the KIZ began to offer the opportunity to acquire language diplomas which served to "enable the holder to take up a scientific qualification in the GDR without further linguistic preparation." 82 The course load for the language diploma comprised 480 hours and was to become mandatory in the future for an entry visa to study in East Germany. During a visit to East Germany by Abdul Wahab el Borolosy, the Egyptian minister of higher education, it was agreed that language training at the KIZ should be concentrated on those who would study in the GDR. In the future, language training should also focus on technical disciplines.

This change in the orientation of German teaching can be seen as an East German paradigm shift in the teaching of DaF. In the 1970s language teaching became more and more a tool to support educational programs. The aim was now a pragmatic preparation for university education in East Germany. Propaganda was no longer in the foreground, although the indoctrination of Egyptian instructors did not disappear completely. For economic reasons, more Egyptian instructors were hired for the teaching of beginners' and basic courses, but for political reasons they were to be "regularly instructed and controlled by East German instructors, as well as politically and methodically supervised.” These

80 SAPMO-BArch, DR3/II/B1022d, 1. Tätigkeitsbericht des Lektorats Kairo, Studienjahr 1969/70, February 20,1970. We found no explanation in the sources to whom the term "housewives" refers and how many of them wanted to enroll in the courses. Unfortunately, there is a general lack of information in the sources about gender of Egyptian students and teachers.

81 SAPMO-BArch, DY 13/2020, Beschlussprotokoll der Sekretariatssitzung der Deutsch-Arabischen Gesellschaft, August 3, 1966.

82 SAPMO-BArch, DR3/II/B1022c, Tätigkeitsbericht des Lektorats am Kulturzentrum in Kairo, August 12, 1969. 
instructors had to attend a further training course in East Germany every two years in order to report on the GDR from their own experience. ${ }^{83}$

East Germany's relative superiority vis-à-vis West Germany in the realm of cultural diplomacy was quickly ended by another change in Egypt's political scene. After Nasser's sudden death in 1970, Egyptian foreign policy under Anwar Sadat changed fundamentally. Egypt moved closer to the West without giving up cooperation with the socialist countries. ${ }^{84} 1972$ saw the resumption of diplomatic relations between West Germany and Egypt. With Egypt's diplomatic recognition of the GDR, cultural diplomacy in North Africa became less central for the two German states. The situation reversed, and less and less visitors were drawn to the East German cultural center. ${ }^{85}$ German lessons continued, but while the Goethe Institute in Cairo still exists today, the GDR closed its cultural and information centers in Cairo and Alexandria in 1977. The closure of the centers was probably not only related to the diplomatic recognition of the GDR, which led to a decline of investments in cultural diplomacy, but also to the deterioration in relations between Egypt and the socialist countries under Anwar al-Sadat. From 1974, Sadat clearly moved closer to the West and, among other things, withdrew from the Treaty of Friendship with the Soviet Union in $1976 .{ }^{86}$

\section{German Language Courses in Egypt and the Emergence of DaF}

The German-German Kulturkampf in Egypt played an important role in the emergence of the academic subject German as a foreign language (DaF). Egypt was the second non-socialist country after Finland in which the GDR experimented with the teaching of German as a foreign language abroad with its own instructors at its own language centers. Until then, there had been little experience with

83 SAPMO-BArch, DR3/II/B1022d, 1. Tätigkeitsbericht des Lektorats Kairo, Studienjahr 1969/70, February 20, 1970.

84 For an overview of the events after Nasser's death and the political change in Egypt see Westad, Cold War, 463-469; Christopher Andrew and Vasili Mitrokhin, The World Was Going Our Way: The KGB and the Battle for the Third World (New York: Basic Books, 2005), 141-142.

85 SAPMO-BArch, DR3/II/B1507/1b, Kurzbericht über das Herbstsemester 1972/73 am Lektorat des KIZ Kairo, March 13, 1973.

86 Praxenthaler, Sprachverbreitungspolitik, 237; Schwanitz, “Zweierlei Deutsche,” 26. 
teaching in a non-German-speaking environment. ${ }^{87}$ The GDR's German classes in Egypt were also successful and attractive because they were carried out by welltrained instructors.

East German instructors were carefully selected to ensure that they had language skills in the host country. A guideline of the East German Ministry of Higher and Technical Education (MHF) for the selection of instructors stated that they should have sufficient foreign language skills "in order to be able to carry out foreign information at a high level in beginners' lessons." 88 In Egypt, this meant that almost all East German instructors were experienced language instructors or German studies experts with knowledge of English and in most cases also with Arabic language skills. Almost all the instructors had previously studied or taught at the Herder Institute in Leipzig. Egyptian authorities often pointed out to West German representatives these qualitative differences between East and West. The Federal Foreign Office therefore insisted that West German instructors should have acquired knowledge of the national language before their assignment. In reality, this could rarely be implemented. There were simply too few West German instructors with knowledge of Arabic who would have been willing to go to Egypt, either out of concern for their careers or out of fear of crisis situations flaring up again and again. ${ }^{89}$

In September 1966, the East German Council of Ministers decided to "establish a comprehensive system of German language teaching for foreigners.” This decision formed the basis for further development of language policy as a focal point of the GDR's cultural diplomacy in order to counter West German language policy. According to the Council of Ministers of the GDR, West Germany only used language courses to "gain political influence in the developing countries and to bind the leaders in these countries to the FRG." The resolution clearly states how the influence of West Germany was to be reduced. The aim, according to the Council of Ministers, should be "to gradually reach firm contractual agreements [...] and political and cultural centers [...] through the secondment of individual instructors." 90 The decision of the Council of Ministers therefore directed that

87 For GDR cultural policy in Finland see Olivia Griese, Auswärtige Kulturpolitik und Kalter Krieg. Die Konkurrenz von Bundesrepublik und DDR in Finnland 1949-1973 (Wiesbaden: Harrassowitz, 2006).

88 SAPMO-BArch, DR3/II/B1022b, AG Deutsch als Fremdsprache, Bericht des Lektorats am Kulturzentrum Kairo der Deutschen Demokratischen Republik in der Vereinigten Arabischen Republik, Sommersemester 1968, no date.

89 Lothar Reinermann, "Die Außenstellen des DAAD in London und Kairo," Spuren in die Zukunft 1 (2000), 186.

90 SAPMO-BArch, DC20/I/4/1412, Ministerratsbeschluss, September 8, 1966. 
German as a foreign language should be underpinned theoretically and practically and had to be developed into an "independent scientific discipline." 91 In a conceptual paper on the development of German as a foreign language, the director of the Herder Institute in Leipzig, Johannes Rößler, stressed that the quantitative superiority of West Germany in the field of DaF could be countered by the qualitative superiority of the GDR. According to Rößler, this lead should be maintained at all costs. ${ }^{92}$ It becomes once again clear at this point how much language teaching was used as a strategic weapon under the conditions of ubiquitous system competition.

Here we can see several factors that influenced German language teaching. The paradigm shift in language education from ideological to technical made it necessary to scientifically underpin language teaching. At the same time, East German party and state leaders noticed that language policy enabled them to compete with West Germany with relatively scarce resources.

In general, teaching German in Egypt was an important step for East German instructors, in their career and at the same time an opportunity to experience life abroad, as can be seen in the case of Gerhard Helbig. It was either a starting point for an international career or a once in a lifetime opportunity. Some used this opportunity for a more radical change. Although authorities took care to ensure that only well-established "cadres" were allowed to travel abroad, it was not possible to prevent the "Republikflucht" [desertion from the republic, i.e. GDR] of instructors completely. ${ }^{93}$ For example, a married couple of instructors who had been employed in Egypt as well as the GDR instructor in Conakry in Guinea used their stay abroad to "defect" to the West. ${ }^{94}$ This sparked a debate between the Herder Institute, the MHF, and the Foreign Office on how to prevent similar events in the future. ${ }^{95}$

The success of the GDR in Egypt promoted the emergence of DaF as an academic subject in the GDR. From a practice increasingly needed during the 1950s

91 SAPMO-BArch, DC20/I/4/1412, Beschluss Aufbau eines umfassenden Systems für den deutschen Sprachunterricht, June 8, 1966.

92 UAL, HI 028, Johannes Rößler, Problemskizze zur Entwicklung des Gegenstandes “Deutsch als Fremdsprache,” August 28, 1973, 140.

93 SAPMO-BArch, DR3/II/B1022e, Günther Hänse and Horst Nalewski, Halbjahresbericht über die Arbeit an der Universität Kairo für die Zeit vom 10. Februar bis 10. Juni 1970, June 10, 1970. 94 The names of the couple are not mentioned. The lecturer from Conakry, however, became lecturer at the Goethe Institute in Munich and later Professor for DaF in Saarbrücken.

95 SAPMO-BArch, DR3/II/B1426d, Brief Leiter des Referats für Wirtschaftliche Auslandsbeziehungen MLU Halle an MHF, January 27, 1969. How many lecturers exactly used their assignment in Egypt as an opportunity to turn their backs on the GDR cannot be determined from the available sources. 
and 1960s it developed into an independent scientific discipline in the GDR, several years before it was established in West Germany. On the one hand, the aim was to offer better German lessons than those of the Goethe Institute or the DAAD in countries like Egypt and thus to convince the students that the GDR was the "better Germany". On the other hand, scientific research was meant to improve and shorten the obligatory German lessons for foreign students in the GDR. At the center of these efforts was the Herder Institute in Leipzig, which from the beginning of the 1950s was the training center for the obligatory preparatory German lessons for foreign students wishing to study in the GDR. Here at the Institute, the foundations were laid for the academic subject of German as a foreign language. In 1967, a research department was founded at the institute, and in 1968, Gerhard Helbig, the former first instructor in Cairo, was appointed as the first chair for German as a foreign language. ${ }^{96}$

\section{Conclusion}

Cultural cooperation between Egypt and the two German states during the Cold War period was a new chapter in the long-standing Egyptian-German relations, which affected the institutions in both German states. This is particularly evident in language policy and in the genesis of the subject German as a foreign language. The debate on language teaching in Egypt had a particular influence on East German language policy, and shaped pioneering institutions like the Herder Institute and Goethe Institute in the Global North on both sides of the Iron Curtain.

The competition of the East German and West German cultural institutes in Cairo shows that Egyptian actors and institutions were in charge and shaped the discourse. For Egyptians, German-German competition was sometimes ignored but, in most cases, instrumentalized or used for tactical maneuvers in the conflict over Israel. Learning German had a long tradition in Egypt ${ }^{97}$ and German was also needed by Egyptians who wanted to study in one of the two German countries. In this respect, teaching German in Cairo was a small piece of the puzzle in the great development project of socialist modernization under Nasser.

\footnotetext{
96 SAPMO-BArch, DC20/I/4/1412, Beschluss Aufbau eines umfassenden Systems für den deutschen Sprachunterricht, June 8, 1966; SAPMO-BArch, DR 3/5938, Herder-Institut der KMU Leipzig, Perspektivplan 1966/70.

97 For this tradition see Aleya Khattab, "Deutsch in Ägypten," in Deutsch als Fremd- und Zweitsprache. Ein internationales Handbuch, ed. Hans-Jürgen Krumm (Berlin, New York: De Gruyter, 2010), 1602-1606.
} 
Egypt under Nasser was on its own path of socialist development and maintained close relationships with the USSR and other socialist countries. Like many non-aligned Third World countries it carefully avoided to choose one side in East West Cold War competition but rather followed its own agenda and interests. The increasingly strong relations with the socialist GDR fit into this pattern. From the Egyptian side they might have been a result of practical and strategic considerations rather than an expression of deeply felt socialist solidarity. Ideological consensus with the GDR was most likely to be found in Egypt's pronounced anti-imperialism.

Solidarity between the GDR and Egypt is perhaps better understood if it is seen not so much as political or economic altruism. Both states were interested in meeting at eye level and wanted to benefit from the exchange. This anti-imperialist win-win situation may not always have existed in practice. Nevertheless, it shaped the decisions on both sides. The East-West side of the triangular relationship described in this chapter was not central for Egypt, but system competition between East and West Germany was used by Egyptian actors to deal with both sides successfully. This is also reflected in the German-German struggle for sovereignty over the teaching of German and the changing reactions of Egyptian actors, be they learners, teachers or political functionaries, which determined the scope of action of the two German states.

In retrospect, however, the decisive question is not whether "Herder" or "Goethe" won the German-German competition in Egypt. Rather, we are challenged to examine a facet of the conflicts in the Cold War. We see the economically unequal two German states competing in one of the leading countries of the Third World movement, without diplomatic recognition by this country and at eye level to each other. We see them engaging in their tough and sometimes seemingly ridiculous cultural struggle over who should be allowed to teach German to Egyptian interested parties. German-German competition had an important side effect on the genesis and institutionalization of the subject of German as a foreign language in East Germany and subsequently also in West Germany. This shows that external missions of projecting cultural soft power in the Global South sometimes had stronger effects on the northern cultural missionaries themselves than on their southern counterparts. 


\section{Bibliography}

Abou-El-Fadl, Reem. "Building Egypt's Afro-Asian Hub: Infrastructures of Solidarity and the 1957 Cairo Conference.” Journal of World History 30 (2019): 157-192.

Abu Samra, Dalia. "Deutschlands Außenpolitik gegenüber Ägypten: Abbruch und Wiederaufnahme der diplomatischen Beziehungen 1965-1972." PhD diss., Freie Universität Berlin, 2002.

Andrew, Christopher, and Vasili Mitrokhin. The World Was Going Our Way: The KGB and the Battle for the Third World. New York: Basic Books, 2005.

Altmayer, Claus. "50 Jahre Herder-Institut, 50 Jahre Deutsch als Fremdsprache. Traditionen und Grenzüberschreitungen.” Deutsch als Fremdsprache 44 (2007): 67-74.

Büren, Rainer. "Die arabischen Staaten in der außenpolitischen Konzeption der Bundesrepublik Deutschland." In Araber und Deutsche. Begegnungen in einem Jahrtausend, edited by Friedrich Kochwasser and Hans Roemer, 11-33. Tübingen, Basel: Erdmann, 1974.

Burton, Eric. "Hubs of Decolonization. African Liberation Movements and Eastern Connections in Cairo, Accra and Dar es Salaam." In Southern African Liberation Movements and the Global Cold War "East": Transnational Activism 1960-1990, edited by Lena Dallywater, Helder A. Fonseca, and Chris Saunders, 25-56. Berlin: De Gruyter, 2019.

Bracher, Karl Dietrich, Gisela Biewer, Ernst Deuerlein, eds. Dokumente zur Deutschlandpolitik. München: Oldenbourg, 1978.

Das Gupta, Amid. "Ulbricht am Nil: Die deutsch-deutsche Rivalität in der Dritten Welt." In Das doppelte Deutschland: 40 Jahre Systemkonkurrenz, edited by Udo Wengstand and Hermann Wentker, 111-134. Berlin: Ch. Links, 2008.

Dinkel, Jürgen. The Non-Aligned Movement: Genesis, Organization and Politics, 1927-1992. Leiden, Boston: Brill, 2018.

Gray, William G. Germany's Cold War: The Global Campaign to Isolate East Germany, 1945-1969. Chapel Hill, London: The University of North Carolina Press, 2003.

Griese, Olivia. Auswärtige Kulturpolitik und Kalter Krieg. Die Konkurrenz von Bundesrepublik und DDR in Finnland 1949-1973. Wiesbaden: Harrassowitz, 2006.

Geerhardt, Herbert. "Kultur- und Wissenschaftsbeziehungen der DDR zu Staaten Afrikas und Asiens.” Deutsche Außenpolitik 13 (1968): 1432-1440.

Hong, Young-Sun. Cold War Germany, the Third World, and the Global Humanitarian Regime. New York: Cambridge University Press, 2015.

Höpp, Gerhard. Texte aus der Fremde. Arabische politische Publizistik in Deutschland, 1896-1945. Eine Bibliographie. Berlin: Das Arabische Buch, 2000.

Kathe, Steffen R. Kulturpolitik um jeden Preis. Die Geschichte des Goethe-Instituts von 1951 bis 1990. München: M. Meidenbauer, 2005.

Khattab, Aleya. "Deutsch in Ägypten”. In Deutsch als Fremd- und Zweitsprache. Ein internationales Handbuch, edited by Hans-Jürgen Krumm, Christian Fandrych, Britta Hufeisen, and Claudia Riemer, 1602-1606. Berlin/New York: De Gruyter, 2010.

Kilian, Werner. Die Hallstein-Doktrin. Der diplomatische Krieg zwischen der BRD und der DDR 1955-1973: Aus den Akten der beiden deutschen Außenministerien. Berlin: Duncker \& Humblot, 2001.

Kramer, Thomas. Deutsch-ägyptische Beziehungen in Vergangenheit und Gegenwart. Tübingen: Erdmann, 1974. 
Lüthi, Lorenz. "The Non-Aligned Movement and the Cold War, 1961-1973." Journal of Cold War Studies 18 (2016): 98-147.

Muehlenbeck, Philipp. Czechoslovakia in Africa 1945-1968. Basingstoke: Palgrave Macmillan, 2016.

Osman, Tarek M. Egypt on the Brink: From the Rise of Nasser to the Fall of Mubarak. New Haven: Yale University Press, 2011.

Peisert, Hansgert. Auswärtige Kulturpolitik der Bundesrepublik Deutschland, Gutachten im Auftrag des Auswärtigen Amts. Konstanz: Auswärtiges Amt, 1971.

Porz, Helga. Zur Entwicklung des Herder-Instituts. Von den Anfängen der Vorbereitung ausländischer Studierender auf ein Studium in der DDR bis 1966. PhD diss, Universität Leipzig, 1972.

Praxenthaler, Martin. Die Sprachverbreitungspolitik der DDR. Die deutsche Sprache als Mittel sozialistischer auswärtiger Kulturpolitik. Frankfurt, Berlin: Peter Lang, 2002.

Reinermann, Lothar. "Die Außenstellen des DAAD in London und Kairo." Spuren in die Zukunft 1 (2000): 177-195.

Schwanitz, Wolfgang G., ed. Berlin-Kairo damals und heute: zur Geschichte deutsch-ägyptischer Beziehungen. Berlin: DÄG, 1991.

Schwanitz, Wolfgang G. “Ägypten: Zweierlei Deutsche im Kalten Krieg.” Comparativ 16 (2006): $11-29$.

van Laak, Dirk. Weiße Elefanten. Anspruch und Scheitern technischer Großprojekte im 20. Jahrhundert. Stuttgart: Deutsche Verlagsanstalt, 1999.

Wentker, Hermann. Außenpolitik in engen Grenzen. Die DDR im internationalen System 1949-1989. München: Oldenbourg, 2007.

Westad, Odd Arne. The Cold War. A World History. New York: Basic Books, 2017.

Winrow, Gareth. The Foreign Policy of the GDR in Africa. Cambridge et al.: Cambridge University Press, 1990.

Yaqub, Salim. "The Cold War and the Middle East". In The Cold War in the Third World, edited by Robert McMahon, 11-26. Oxford et al.: Oxford University Press, 2003. 
